\title{
Systems Approach to Eastern Baltic Coastal Zone Management
}

\author{
Eglè Baltranaitè ${ }^{1, * \mathbb{D}}$, Ramūnas Povilanskas ${ }^{1, * \mathbb{D}}$, Kęstutis Dučinskas ${ }^{2}$, Raimonds Ernšteins ${ }^{3}$ \\ and Hannes Tõnisson 4 \\ 1 Marine Research Institute, Klaipeda University, Universiteto ave. 17, LT-92294 Klaipėda, Lithuania \\ 2 Department of Informatics and Statistics, Faculty of Marine Engineering and Netural Sciences, \\ Klaipeda University, H. Manto st. 84, LT-92294 Klaipėda, Lithuania; kestutis.ducinskas@ku.lt \\ 3 Department of Environmental Science, Environmental and Coastal Governance, University of Latvia, \\ Raina blv. 19, LV-1586 Rīga, Latvia; raimonds.ernsteins@lu.lv \\ 4 Institute of Ecology at Tallinn University, Uus-Sadama 5, EE-10120 Tallinn, Estonia; annu@tlu.ee \\ * Correspondence: egle.baltranaite@gmail.com (E.B.); ramunas.povilanskas@gmail.com (R.P.)
}

Received: 23 September 2020; Accepted: 26 October 2020; Published: 4 November 2020

check for updates

\begin{abstract}
Relying on the results of multivariate analysis of the re-analysis case studies from the BaltCoast project, specific features of integrated coastal management (ICM) approaches in Estonia, Latvia, Lithuania, and the Kaliningrad Oblast of the Russian Federation are highlighted in this paper. Eleven Eastern Baltic ICM case studies have been re-analyzed in-depth, which was the main focus of the present paper, covering a wide range of coastal landscapes, themes, policy issues, and ICM approaches. Five principal components explaining $84.86 \%$ of the total variance of ICM factor scores have been elicited by calculating rotation sums of squared loadings: (1) Stakeholder Involvement; (2) Research Base; (3) Planning Consistency; (4) Policy Environment, and (5) Development of Plans/Strategies. A truly dedicated involvement of a wide range of stakeholders throughout all process stages showed to be critical for further successful advance of ICM processes and principles based on the systems approach in the Baltic States and the Russian Federation.
\end{abstract}

Keywords: Baltic states; integrated coastal management; systems approach framework; Stakeholder involvement; retrospective analysis

\section{Introduction}

Sustainable and truly Integrated Coastal Management (ICM) requires a systems approach that stretches beyond linear linking of causes and effects and forms strategies to elicit knowledge on the functioning of complex systems, which is necessary to understand the complexity of coastal environments. According to Hopkins et al. [1] "This reflects the systems theory caveat that understanding the structure (composition) does not necessarily permit an understanding of the function (dynamic purpose). Consequently, investigating a system's interactions can increase our understanding of its function beyond that gained by information only on the status of its components." Differently from analytical approaches favoring a reductionist focus, the systems approach is an iterative process of an issue-oriented, multidisciplinary investigation, which requires a holistic perspective and integrates the three pillars of sustainable development: environmental protection, social progress and economic growth [2-4].

Reflecting the need to facilitate the holistic perspective and systems approach in ICM, an Integrated Project SPICOSA (Science and Policy Integration for Coastal Systems Assessment) supported by the European Union (EU) 6th Framework Programme between 2007 and 2011 has developed a Systems Approach Framework (SAF). Along with accompanying support tools, it is a self-evolving, 
holistic research methodology for the integrated assessment of sustainable coastal development policy options relying on outputs from a number of virtual scenarios [2,5]. As noted by Newton [6]: "The SAF is not a strict methodology, it is truly a framework that can be used and adapted to different coastal systems, different issues, different stakeholders, and different countries. [ ... ] The SAF is a space that enables useful Coastal System Assessment and Science-Policy Integration so that scientific information can better inform decision-makers."

Over 20 papers have been published on various aspects of SAF in peer-reviewed academic journals since the development of the SAF as a result of the SPICOSA project [1-3,6-8]. The project 'Systems Approach Framework for Coastal Research and Management in the Baltic' (BONUS BaltCoast) was the next comprehensive effort, after SPICOSA, in SAF development and application in the Baltic Sea Region (BSR). The first stage in the implementation of BaltCoast focused on the application of the SAF methodology to assess retrospectively how well SAF elements had been applied in practice within ICM processes.

In that stage, a comprehensive, in-depth retrospective analysis (re-analysis) was done by an international expert team, if and at what point a SAF approach would have been beneficial for the re-evaluated case studies. It was based on joint, standardized criteria, and followed strict guidelines. For this aim, the project team used an online database of the ICM best practice case studies compiled by an international partner network of EUCC-Coastal and Marine Union within the OURCOAST project initiated by the European Commission [4]. The database of the case studies covered the entire EU comprising a peer-reviewed collection of the European best-practice ICM case studies and including over 30 ICM case studies in the BSR [9].

A total of 20 completed and ongoing ICM case studies undertaken in all nine Baltic Sea countries and covering a wide range of coastal themes and key approaches have been chosen for the re-analysis. Based on joint, standardized criteria, a Strengths-Weaknesses-Opportunities-Threats (SWOT) analysis has been carried out for each case study as well as an analysis whether the application of SAF would have been beneficial [4]. Most of the experts had been responsible or involved in national OURCOAST case study descriptions, and half of the selected case studies were taken from the OURCOAST database. To include also Russian case studies, and to allow for broad coverage of issues and approaches, the other half of case studies have been taken from other local or national initiatives. According to Støttrup et al. [4], the key selection criteria were the following:

(1) The case study had to address complex coastal management issues, which require an ICM-based approach;

(2) It should include an advanced process where at least a draft solution has been developed and agreed by the involved actors;

(3) It should include a balanced mixture of themes and approaches;

(4) Information on both the process and its outcomes had to be available, either as written documentation or by access to more than one involved key person.

The aim of the present study is, relying on the re-analysis results of the case studies within the BaltCoast project, to investigate the specificity of ICM approaches regarding the SAF in the three Baltic States-Estonia, Latvia, and Lithuania-and the Kaliningrad Oblast of the Russian Federation. Our central argument is that if we aim to pursue a genuine systems approach, and if we want to identify perspectives and premises for successful application of the SAF in various ICM systems, then, we must properly address a discrepancy between the broad-scale scientific knowledge and methods applied in the SAF and how important, credible, and useful these methods are considered at the regional level referring to differing cultural and historical backgrounds [3].

To demonstrate this argument and to discuss its implications, this paper is organized as follows: it begins with an introduction into the methods, materials, and the description of the Eastern Baltic coastal zone as the study area. In the 'Results' section, first, we analyze the outputs of multivariate analysis (MVA), aiming to elicit and discuss the principal components that determine the specifics 
of the ICM processes regarding the SAF based on the re-analyzed case studies. Then, we present a comparative analysis of the SAF-related ICM case-studies in Estonia, Latvia, and Lithuania, and the Kaliningrad Oblast of the Russian Federation.

The discussion focuses on what are the main reasons for differences and similarities of the ICM approaches in Western and Eastern Baltic countries, particularly, of the ICM approaches in the Baltic States and the Russian Federation in comparison with Finland. The paper concludes by noting that, besides the simulation model-based production of coastal zone development scenarios, a truly dedicated involvement of a wide range of stakeholders throughout all process stages is critical for further successful advance of the SAF-based ICM processes and principles in the Eastern Baltic countries.

\section{Materials and Methods}

The methodology of the BaltCoast case study re-analysis has been described in a detailed, stepwise way by Støttrup et al. [4]. As already mentioned above, the survey included a SWOT analysis on the overall quality of the ICM process (expert judgement) and on external and internal risks and opportunities that may further affect the process (expert judgement). After the review of the draft survey material by a panel of national ICM experts, these national experts conducted interviews in local languages with participants of the respective case study processes and consolidated them by summing them up in one completed questionnaire for each case study.

For this paper, we have used available qualitative and quantitative information from the re-analysis case study database delivered by the BaltCoast project partnership network. The national case study re-analysis reports were reviewed, and the SWOT scores for each re-analysis study were compiled by the authors of this paper. To make the database of the SWOT scores better suitable for MVA, we have included 20 available case studies in the present analysis, with two extra case studies from Lithuania, reflecting local ICM policy issues, additionally analyzed for this paper: Denmark (two), Estonia (two), Finland (two), Germany (four), Latvia (three), Lithuania (four), Poland (two), Russia (two), Sweden (one). Hence, altogether, 11 Eastern Baltic ICM case studies have been re-analyzed in-depth being the main focus of the present paper and covering a wide range of coastal landscapes, themes, policy issues, and ICM approaches (Figure 1 and Table 1).

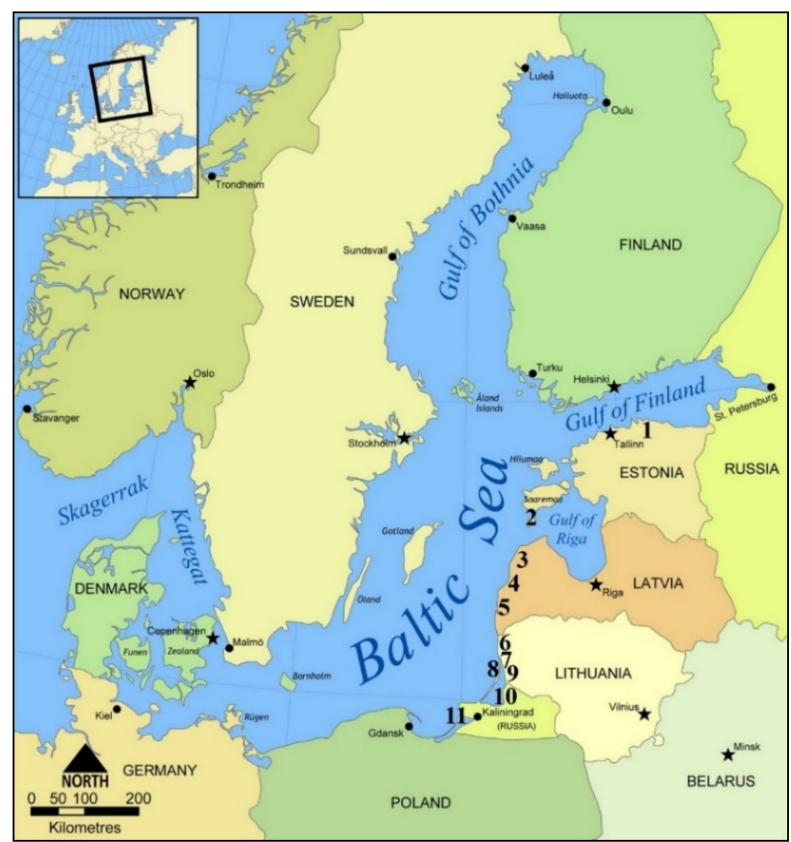

Figure 1. Map of the Baltic Sea with the re-analysis case study sites in Estonia, Latvia, Lithuania, and Kaliningrad Oblast of the Russian Federation (Map source: Wikipedia). 
Table 1. Themes of the Eastern Baltic re-analysis studies.

\begin{tabular}{cc}
\hline Country & $\begin{array}{c}\text { Analyzed Case Studies (Numbers Refer to Figure 1) } \\
\text { Estonia }\end{array}$ \\
\hline 2. The Järve-Nasva case-study site on Saaremaa island-coastal protection
\end{tabular}

The quantitative data interpretation by applying MVA has been conducted using the scores given by the national ICM experts to the strengths and weaknesses of the re-analyzed case studies in relation to the SAF according to the different SWOT factors (Table 2). For this aim, the scores attributed by the experts to 22 SWOT factors in 22 re-analysis case studies have been used as a database. The factor analysis, which was aimed to identify the principal components and their relative square loadings in total variance, was done by applying principal component analysis with rotation. The rotation method applied in the analysis was Varimax with Kaiser normalization. For calculating the rotated component matrix, the rotation converged in six iterations.

Table 2. Strengths-Weaknesses-Opportunities-Threats (SWOT) factors regarding the Systems Approach Framework (SAF) of the re-analyzed Integrated Coastal Management (ICM) case studies.

\begin{tabular}{cc}
\hline Aspect & Factors \\
\hline Management & 1. Scientific Team \\
& 2. Management experience \\
3. Systematic approach & 4. Background work \\
& 6. Data evaluation \\
5ssessment & 1. Identification of the major stakeholders and their interests \\
& 7. Assessment of the central ecological, social, and economic issues \\
8. Review and feedback of the assessment by the stakeholder \\
9. Definition of a joint objective
\end{tabular}


After evaluating a number of components predetermined in the planning phase, five principal components amounting to $84.86 \%$ of total variance of ICM factor scores have been elicited by calculating rotation sums of squared loadings: (1) Stakeholder Involvement; (2) Research Base; (3) Planning Consistency; (4) Policy Environment, and (5) Development of Plans/Strategies. In the next step of the factor analysis, i.e., for eliciting and validation of inter-relationships of five principal components, three additional matrixes have been calculated: a component transformation matrix, a component score coefficient matrix, and a component score covariance matrix. The latter one validated the results of the factor analysis (Table 3). The last step in the MVA was to calculate integrated indexes for different principal components and for different sub-regions: Eastern Baltic (Estonia, Latvia, Lithuania, Poland, and Russia), Western Baltic (Denmark, Germany, Finland, and Sweden), and, separately, for each of the Baltic States and Kaliningrad Oblast of Russia, as well as Finland.

Table 3. Component Score Covariance Matrix (1. Stakeholder Involvement; 2. Research Base; 3. Planning Consistency; 4. Policy Environment, and 5. Development of Plans/Strategies).

\begin{tabular}{cccccc}
\hline Component & $\mathbf{1}$ & $\mathbf{2}$ & $\mathbf{3}$ & $\mathbf{4}$ & $\mathbf{5}$ \\
\hline 1 & 1 & 0 & 0 & 0 & 0 \\
\hline 2 & 0 & 1 & 0 & 0 & 0 \\
\hline 3 & 0 & 0 & 1 & 0 & 0 \\
\hline 4 & 0 & 0 & 0 & 1 & 0 \\
\hline 5 & 0 & 0 & 0 & 0 & 1 \\
\hline
\end{tabular}

\subsection{Study Area}

\subsubsection{General Overview}

The study area of the present paper is the coastal zone in four countries of Northern Europe (Figure 1). The Baltic States (Estonia, Latvia, and Lithuania), and Kaliningrad Oblast of the Russian Federation are located on the eastern fringe of the Baltic Sea, which is a semi-enclosed sea and the largest body of brackish water in the world [8]. In terms of sub-basins of the Baltic Sea proposed by the Baltic Marine Environment Protection Commission [10], the study area covers the Baltic Sea coasts in the Gdansk Basin, the Eastern Gotland Basin, the Gulf of Riga, the Northern Baltic Proper, and the Gulf of Finland.

Eastern Baltic countries have a relatively long history in coastal research, but their experience in ICM of the standards, which were compatible with those of the Nordic or Western European countries, is relatively short. From 1945 to 1990, the eastern part of the Baltic Sea and the coastal zone from Poland to Finland belonged to a single political entity, the Soviet Union. It comprised a vast maritime, coastal, and terrestrial area, which was administratively divided between five autonomous provinces of the Soviet Union (three union republics-Estonia, Latvia, and Lithuania, and two oblasts of the Russian Federation-Leningrad and Kaliningrad) with their economic specializations and nature protection approaches.

Due to geopolitical circumstances, coastal research in the study area was restricted by numerous regulations, and the results of coastal surveys were by and large classified, non-georeferenced, and not accessible to foreign researchers.

Moreover, the official policy of environmental management in the Soviet Union was split between two contrasting concepts: on the one hand, the environment was considered as an unlimited resource, on the other, environment as something which requires protection [11]. The last position was imposed on coastal protected areas and a restricted frontier zone, whereas the first position had been applied to most other coastal sites, e.g., seaports, multimodal transport hubs, naval bases, and their adjacent areas.

Such a double approach has resulted in an excessive emphasis on functional zoning, and lack of any integration or systems approach in coastal management [12]. Therefore, in 1991, after the collapse 
of the Soviet Union, the newly-independent Baltic States and the Russian Federation immediately faced numerous problems and challenges in the protection of the Baltic Sea environment, and an acute need for integrated management of the Baltic coastal zone [11]. Like other Baltic Sea countries, the Baltic States and Russia gain substantial economic benefits from the marine ecosystems and the coastal zone, especially through revenue from fisheries and tourism [8]. Therefore, any human-induced decline of quality and integrity of the aquatic and coastal environment has negative effects on economic and social welfare, particularly in coastal regions of these countries. Hence, there is the need for a systems approach to coastal management.

\subsubsection{Estonia}

Estonia has the longest Baltic Sea coastline $(3794 \mathrm{~km})$ among the Baltic States [13]. The Estonian coastal zone in the Baltic Sea involves areas in the open part of the Baltic Sea, in the Gulf of Finland and the Gulf of Riga. Before 2011, ICM as a land-use approach of the national or regional level designed to access and balance the concerns of various coastal zone interests was largely missing in Estonia [14]. Starting with the adoption of the EU Directive on Maritime Spatial Planning (MSP) in 2014 (2014/89/EU), ICM became an integral part of the regional level plans for MSP. In the last 10 years, ICM-relevant research in Estonia focused on coastal zone development in the context of the increasing human impact and global climate change [14-19].

\subsubsection{Latvia}

Latvia has $497 \mathrm{~km}$ of the Baltic Sea coastline, of which $253 \mathrm{~km}$ is the coast of the Gulf of Riga, and $244 \mathrm{~km}$ is the coast of the Baltic Sea [20]. It provides living space for about 0.9 million people, which is $45 \%$ of the country's population [21,22]. The Sustainable Development Strategy of Latvia until 2030 acknowledges that the Baltic Sea coast is a unique area of national interest, where preservation of nature and cultural heritage is balanced with economic development. In 2011, the Ministry of Environmental Protection and Regional Development has adopted State Coastal Spatial Development Guidelines for 2011-2017.

In 2016, the Long-Term Thematic Plan for the Development of Baltic Sea Coastal Public Infrastructure was elaborated. With the adoption of the EU MSP Directive in 2014, the ICM planning process was integrated into the development of the national MSP plan, being under approval now. In the 21st century, ICM-relevant research in Latvia mainly focuses on mitigation of coastal erosion effects resulting from the global climate change [23-25], and on sustainable coastal governance systems in coastal municipalities [26-31].

\subsubsection{Lithuania}

Lithuania has just $90 \mathrm{~km}$ of the Baltic shoreline, which accommodates a UNESCO World Heritage landscape (Curonian Spit), a large seaport, Klaipeda, and a large seaside resort (Palanga-Šventoji). Hence, there is a need for ICM on a national scale. The advantage of Lithuania is its short coastline, and that $70 \%$ of it is protected, which is within one planning region and just four municipalities. The short coastline gives an advantage for meeting stakeholders needs within a single ICM plan. The main disadvantage is the challenge to accommodate too many interests in a limited coastal area implying conflicts between seaport development, nature conservation, and recreation. Therefore, already at the beginning of the 21st century, ICM became a priority in Lithuania [32].

The Law of the Coastal Zone was adopted by the Lithuanian Parliament in 2002. It was followed by the National ICZM Programme approved by the Ministry of Environment in 2003. In the last 10 years, ICM-relevant research in Lithuania mainly focused on the assessment of coastal processes under increasing human impact and global climate change [33-36], seaside resort management integration into the National ICM Programme [37-40], and integrated management of the Curonian Spit as a UNESCO World Heritage landscape [41-43]. 


\subsubsection{Kaliningrad Oblast of Russia}

Kaliningrad Region (Oblast) is an exclave of Russian Federation sandwiched between two EU countries-Poland in the south and Lithuania in the north-that share two large coastal lagoons: Vistula Lagoon with Poland and the Curonian Lagoon with Lithuania, also sharing the catchment of the Neman River-the largest tributary of the Curonian Lagoon. The Baltic Sea coastline within Kaliningrad Oblast extends for 220 km [44]. The advancement of ICM in Kaliningrad Oblast mainly relies on cross-border collaboration projects of academic and environmental protection agencies with counterparts in Poland and Lithuania and primarily deals with the mitigation of coastal erosion where most of the ICM-related research efforts are currently concentrated [45-48].

\section{Results}

\subsection{Principal Components of ICM Factors}

Five principal components explaining $84.86 \%$ of the total variance of ICM factor scores in the re-analysis case studies have been elicited by calculating both extraction and rotation sums of squared loadings (Table 4). As is evident from the component transformation matrix (Table 5), both extraction and rotation sums of squared loadings are well-correlated. However, the results given in Table 4 show that the rotation sums of squared loadings deliver a more balanced distribution of explained variance among the principal components than the extraction sums of squared loadings.

Table 4. The total variance of the ICM factors in the re-analysis case studies explained.

\begin{tabular}{ccccc}
\hline \multirow{2}{*}{\begin{tabular}{c} 
Component \\
\cline { 2 - 5 }
\end{tabular}} & $\begin{array}{c}\text { Extraction Sums of } \\
\text { Squared Loadings }\end{array}$ & \multicolumn{2}{c}{ Rotation Sums of Squared Loadings } \\
\cline { 2 - 5 } Cumulative \% & Total & 7.391 & 33.596 & 33.596 \\
\hline \%takeholder involvement & 49.368 & 4.963 & 22.557 & 56.153 \\
\hline Research Base & 63.980 & 2.631 & 11.961 & 68.114 \\
\hline Planning Consistency & 72.595 & 2.396 & 10.891 & 79.005 \\
\hline Policy Environment & 79.910 & 1.288 & 5.854 & 84.859 \\
\hline Plans/Strategies & 84.859 & & & \\
\hline
\end{tabular}

Table 5. Component transformation matrix.

\begin{tabular}{cccccc}
\hline Component & $\begin{array}{c}\text { Stakeholder } \\
\text { Involvement }\end{array}$ & Research Base & $\begin{array}{c}\text { Planning } \\
\text { Consistency }\end{array}$ & $\begin{array}{c}\text { Policy } \\
\text { Environment }\end{array}$ & $\begin{array}{c}\text { Development of } \\
\text { Plans/Strategies }\end{array}$ \\
\hline Stakeholder involvement & 0.749 & 0.504 & 0.302 & 0.278 & 0.127 \\
\hline Research Base & -0.606 & 0.775 & 0.159 & 0.074 & -0.047 \\
\hline Planning Consistency & -0.213 & -0.374 & 0.735 & 0.509 & -0.125 \\
\hline Policy Environment & -0.094 & -0.023 & -0.554 & 0.797 & 0.219 \\
\hline $\begin{array}{c}\text { Development of } \\
\text { Plans/Strategies }\end{array}$ & -0.135 & -0.072 & 0.190 & -0.149 & 0.958 \\
\hline
\end{tabular}

It is clear from the rotated principal component matrix of standardized ICM factor scores in the re-analysis case studies (Table 6), that the elicited five principal components explaining $84.86 \%$ of the total variance of the factor scores can be categorized as follows: (1) Stakeholder Involvement; (2) Research Base; (3) Planning Consistency; (4) Policy Environment, and (5) Development of Plans/Strategies. It comes as no surprise that Stakeholder Involvement and Research Base are two key principal components explaining over $50 \%$ of the total variance of the scores attributed by the experts to the ICM factors. As our own experience from an in-depth re-analysis of 11 ICM case studies in the Baltic States and Kaliningrad Oblast of Russia shows, the role of these two components in assuring 
successful and systematic ICM process in various cases is hard to overestimate. This observation is rectified by Hopkins et al. [1] arguing that the SAF methodology requires three principal skills:

(1) Using systems thinking to set up and interpret a simulation analysis;

(2) Conducting transdisciplinary assessments of the interactions between the ecological, social, and economic dimensions;

(3) Engaging the participation of stakeholders, ensuring their collaboration with researchers, and communicating the SAF results to a broader public.

Table 6. Rotated principal component matrix of standardized ICM factor loadings (1. Stakeholder Involvement; 2. Research Base; 3. Planning Consistency; 4. Policy Environment, and 5. Development of Plans/Strategies).

\begin{tabular}{|c|c|c|c|c|c|}
\hline \multirow{2}{*}{ Factors } & \multicolumn{5}{|c|}{ Component } \\
\hline & 1 & 2 & 3 & 4 & 5 \\
\hline Scientific Team & & 0.864 & & & \\
\hline Management experience & 0.625 & & & & \\
\hline Systematic approach & & 0.859 & & & \\
\hline Background work & 0.662 & & & & \\
\hline $\begin{array}{l}\text { Identification of the major stakeholders and their } \\
\text { interests }\end{array}$ & & 0.703 & & & \\
\hline Data evaluation & & 0.838 & & & \\
\hline $\begin{array}{c}\text { Assessment of the central ecological, social, and } \\
\text { economic issues }\end{array}$ & & 0.829 & & & \\
\hline $\begin{array}{c}\text { Review and feedback of the assessment by the } \\
\text { stakeholder }\end{array}$ & 0.825 & & & & \\
\hline Definition of a joint objective & 0.801 & & & & \\
\hline Models, scenarios, and cost-benefit analysis & & 0.861 & & & \\
\hline Supportive policy environment & & & & 0.884 & \\
\hline Development of a management plan/strategy & & & & & 0.861 \\
\hline Public involvement/involvement of the affected & 0.960 & & & & \\
\hline Local peoples' experience used & 0.699 & & & & \\
\hline Public and administrative support of ICZM & 0.564 & & & & \\
\hline Number of participants & 0.876 & & & & \\
\hline Active involvement of stakeholders & 0.922 & & & & \\
\hline Communication & 0.823 & & & & \\
\hline Monitoring planning & & & 0.909 & & \\
\hline Space for discussions & 0.530 & & 0.734 & & \\
\hline Transparent results & 0.570 & & & 0.510 & \\
\hline Regular evaluation & & & 0.561 & 0.627 & \\
\hline
\end{tabular}

Extraction Method: Principal Component Analysis. Rotation Method: Varimax with Kaiser Normalization; a rotation converged in six iterations.

\subsection{Stakeholder Involvement}

Considering Stakeholder Involvement as the first principal component, the most important factors of the SAF-related ICM process are: public involvement/involvement of the affected in the planning phase (standardized loading value is 0.960), the review and feedback of the assessment (0.825), as well as the definition of a joint objective by the stakeholders (0.801) in the assessment phase, and active involvement of stakeholders (0.922), their number (0.876), as well as regular and 
efficient communication between the experts, policymakers, and other stakeholders (0.823) in the implementation phase.

The success of the SAF-based ICM lies in exploring actual coastal processes in situ while taking into account the diversity of stakeholders, their coastal management knowledge, and cultural background [3]. According to Reis [5] and Lowe et al. [8], the results of the SPICOSA project show that stakeholder identification and conceptual mapping are the most useful parts of the SAF process, while mathematical model outputs are beneficial for providing a stimulus to enhanced decision-making, as opposed to providing a mechanism for achieving definitive answers. The inclusion of decision-makers and other stakeholders in the review and feedback of the assessment of ICM planning has a clearly defined goal, namely establishing concrete, meaningful, and realistic ways of measuring success [3].

\subsection{Research Base}

Regarding the Research Base as the second principal component, the most important factors of the SAF-related ICM process are: availability and quality of the scientific team (standardized loading value is 0.864$)$, systematic approach (0.859) and data evaluation (0.838) in the management phase, assessment of the central ecological, social, and economic issues (0.829) in the assessment phase, as well as availability and appropriateness of models, scenarios, and cost-benefit analysis (0.861) in the planning phase.

Building a dedicated, interdisciplinary scientific team is one of the keys to a successful, SAF-based ICM process. Yet this is not an easy task. According to Reis [5], the SAF skills which are considered hard to find (e.g., interdisciplinary, practical management, and economics) are also considered to be required skills for effective ICM. Particularly, environmental economists are seen to be difficult to recruit to the field. The need of systematic approach to ICM as one of the main success factors is aptly described by Hopkins et al. [1]: "Asking the right question, correctly formulating the system, and interpreting the results requires systems-thinking skills. [ ... ] The absence of systems thinking makes policy vulnerable to being ineffective and inefficient."

Hopkins et al. [1] also emphasize the role of data evaluation for the success of the SAF-related ICM, since most of SAF efforts use data already collected for other purposes. Such data are often inadequate and fragmented, requiring the scientific team to simplify simulations by educated approximations. Hence, there is a need for compatible, multidisciplinary databases, which are essential for augmenting our capacity to analyze complex social-ecological systems. On the other hand, careful selection of data prevents the modelling in the SAF from being unnecessarily complex. It is particularly important as the outputs of the evaluation are envisaged to be management options that would be suggested to policymakers. Clarity is, therefore, essential [49].

\subsection{Planning Consistency, Policy Environment, and Developing Plans/Strategies}

The other three of the elicited principal components-Planning Consistency, Policy Environment, and Developing Plans/Strategies-altogether explain $28.71 \%$ of the total variance of the scores attributed by the experts to ICM factors of the re-analysis case studies. The most important of the factors in this respect are: monitoring planning in the evaluation phase (standardized loading value is 0.909 ), as well as supportive policy environment (0.884) and development of a management plan/strategy (0.861) in the planning phase.

Monitoring planning and iteration of simulated measures and responses across spatial and temporal scales is the central aspect of a systemic approach to ICM [3]. Comprehensive and iterative monitoring of the interactions between societal and ecological systems may lead to providing grounded simulations of policy options aimed to incorporate objective science into management [1]. Often the iteration processes use the feedback loops between social and ecological components of coupled social-ecological systems (SES) within the analytical framework of Drivers, Pressures, States, Impacts, and Responses (DPSIR) [8,49]. 
Considering the importance of supportive policy environment as a factor of successful SAF-based ICM, McFadden and Schernewski [3] highlighted four lessons from a cross-border ICM case study of the Szczecin Lagoon addressed in the SPICOSA project. Lesson 1: All systems-based projects should explicitly promote the development of effective social learning processes. Lesson 2: A greater focus on 'soft spaces' could facilitate decision-making processes which reflect the complexities of development in coastal systems. Lesson 3: Facilitating a greater understanding of the dominant role of historicity strengthens systems analysis. Lesson 4: Understanding the limitations of a systems approach is important in the ICM target areas as 'arenas of practice' (i.e., participatory platforms open to serendipity).

The development of a comprehensive management plan or a strategy, which is based on iterative simulation of impacts and responses and relying on local knowledge, is crucial as a SAF-based ICM factor as shown by the experience of both SAF-focused research projects: SPICOSA [1] and BaltCoast [4]. The lack of a planned approach to environmental policy is a critical obstacle to policy effectiveness. As noted by Hopkins et al. [1]: "SAF provides a low-cost methodology for planning and evaluating options for sustainable development in coastal zone systems. As in chess, one needs to plan far beyond the next move."

\subsection{Comparison of Western and Eastern Baltic ICM Policy Issues}

Involvement of stakeholders into the ICM process is much higher in Western Baltic countries, Finland in particular. According to Støttrup et al. [4], of all the BaltCoast re-analysis case studies, $25 \%$ of them were initiated by stakeholders, which ensured their participation in the ICM process. An absolute majority of the case studies initiated by stakeholders are from Western Baltic countries-Denmark, Finland, Germany, and Sweden. This is mainly due to a lack of participatory democracy traditions in former totalitarian Eastern Baltic countries. Remarkably, 28 years after reunification, stakeholder participation was still problematic in resolving an ICM Policy Issue on the coast of former East Germany, as the re-analysis case study of Markgrafenheide-Hütelmoor shows [50].

Scientific grounding of the ICM Policy Issues, especially based on simulation models, is more often applied in the re-analysis case studies of the Eastern Baltic countries. This does not imply a ubiquitous application of SAF-tailored simulation models and outputs in Eastern Baltic ICM Policy Issues. However, in the Eastern Baltic countries, research institutes and universities, rather than private consultants, still play the leading role in ICM. Academic experts from the Eastern Baltic research institutes and universities are institutionally, and often personally, interested in the application of those simulation models of which they have the best command to simulate coastal development scenarios and inform policymakers. Reciprocally, Eastern Baltic policymakers and other stakeholders by and large rely on local academic expertise and modelling outputs in decision-taking on ICM.

Planning consistency is slightly higher in the Western Baltic countries, although both planning and its policy environment are rather weak in all countries. The duration of some of the ICM processes re-analyzed in BaltCoast was prolonged due to lack of planning consistency and stakeholder involvement [4]. Schernewski et al. [50] observed that changing political frameworks and local contacts can hamper the ICM planning and implementation process. Although Finland shows relatively good planning consistency, according to [4], the high rank of the two Finnish re-analysis case studies might be due to these being planning strategies and not addressing specific Policy Issues.

\subsection{Comparison of ICM Policy Issues in the Baltic States and Kaliningrad Oblast}

Two ICM Policy Issues have been re-analyzed in Estonia regarding the SAF: (1) the Kunda Port Development Policy Issue focused on the selection of an appropriate port location considering adjacent coastal amenities (sand beaches, salmon-spawning habitats, etc.); (2) the Järve-Nasva case-study site on the Saaremaa Island focused on coastal protection. Keeping the integrity and dynamic equilibrium of the coastal zone was a priority issue in both studies. 
In the Kunda Port case study, different kind of map were used and instrumental surveys carried out during the preparatory stage. Negotiations were held with different stakeholders until the right place for the port was finally fixed. After constructing the port, a monitoring program was launched in order to reveal possible undesirable effects. Similarly, in the Järve-Nasva case study site, functional zoning helped divide the coastal zone into different zones and areas that specify various use and coastal management options. As a result, both Estonian re-analysis case studies rectify the notion that due to its stringent structure, the SAF can be a suitable quality assurance for sustainable ICM processes [4].

In Latvia, three ICM Policy Issues have been re-analyzed regarding the SAF: (1) The use of diverse instruments to ensure multi-use sustainability in a port city, which analyzed the case of the voluntary municipal environmental licensing system in Ventspils; (2) conservation and management of the Pavilosta Gray Dune, which is the most comprehensive long term public self-organized process for Natura 2000 site establishment and management in Latvia; (3) spatial/thematic planning of beaches and nearby coastal zone development in Liepaja city. All three case studies are among those $25 \%$ of all the BaltCoast re-analysis case studies that, according to Støttrup et al. [4], were initiated by stakeholders.

In general, Latvian experts are the most critical among all other experts in the Baltic States in assessing every aspect of ICM in relation to the SAF with $\overline{\mathrm{I}}$ scoring the lowest value for Planning Consistency in the entire Baltic Sea Region. The main critical issue related to the ICM situation in Latvia is a deficiency of coastal (and ICM) complexity, SES understanding, and stakeholders' collaboration [29]

Four ICM Policy Issues have been re-analyzed in Lithuania regarding the SAF: (1) Integrated shoreline management for a large harbor city (Klaipeda) and an adjacent seaside resort (Palanga); (2) Community-based coastal conservation initiatives in the Littoral (Pajūrio) regional park; (3) Integrated mobile dune habitat conservation on the Curonian Spit; (4) Restoration of important habitats through sustainable agricultural practices on the Rusne Island of the Nemunas River Delta.

Like in Estonia or Latvia, the National ICM Program in Lithuania was developed and approved at a national level. One administrative level below, the implementation of the ICM program has been entrusted with the administration of the Klaipeda region. In Lithuania, there was no active involvement of regional and/or local stakeholders in the preparation and implementation of the ICM program. Therefore, in terms of the SAF, the re-analyzed ICM Policy Issues in Lithuania ought to be much more systematic and comprehensive. A relative success and continuity of ICM measures in Lithuania largely depend upon 'top-down' efforts and long-term support from the EU Structural Funds (Figure 2).

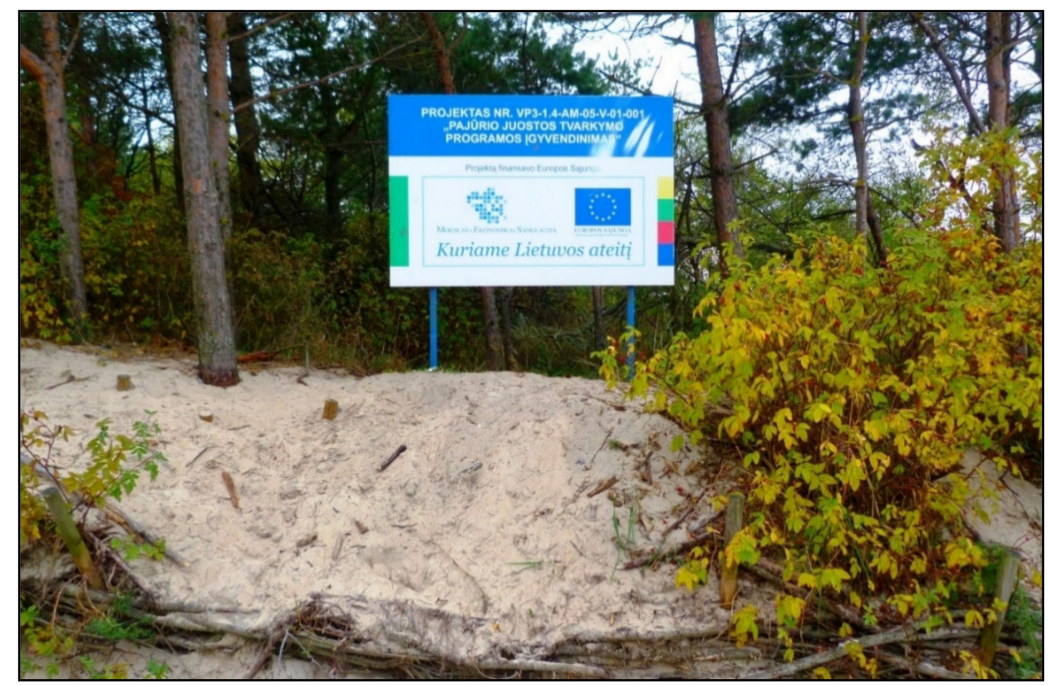

Figure 2. ICM case study site in Palanga, Lithuania, where beach nourishment and other coastal management measures are partly supported by the EU Structural Funds (Photo by Ramūnas Povilanskas). 
Regarding the SAF, two transboundary ICM Policy Issues have been re-analyzed in Kaliningrad Oblast of the Russian Federation: (1) Management of the Russian part of the cross-border Neman River Catchment; (2) Cross-border integration of the Vistula Lagoon management. As demonstrated by the results of SPICOSA, the SAF is valid for transboundary coastal settings and systems (Newton 2012).

\section{Discussion}

In the early stages of SAF development, Tett et al. [51] have broken down the SAF process into five key stages:

- Stage 1. Issue identification-a consultation procedure between scientists, stakeholders, and managers to identify specific impacts from human activity affecting ecosystem services. Once an issue has been identified a number of scenarios are suggested as possible solutions.

- Stage 2. System design - takes the issue(s) and scenarios and develops a conceptual model that links the real world with the virtual world.

- Stage 3. System formulation-develops the appropriate mathematical formulae to convert the conceptual model into a quantitative simulation model.

- Stage 4. System appraisal—quantitative simulations are appraised by environmental, economic, and social experts.

- Stage 5. System output-stakeholders and managers are shown the consequences of implementing a range of policy options, thereby facilitating informed deliberation and evidence-based policy development.

One can notice that area managers and lay stakeholders are given only tertiary roles in this scheme, after scientists and experts. First, they are included in the process of issue identification and, second, they are presented with the consequences of implementing a range of policy options. Although such a logical, stepwise flowchart can be very tempting because of its simplicity, it quickly becomes tedious since it represents a prototype, much emptier than the reality it refers to, as was shown by critical reflections on a number of SAF case studies $[3,4,49,50,52,53]$.

Once again referring to the seminal paper by Hopkins et al. [1]: "The value of the systems approach is the capacity to answer functional questions about complex systems. However, its application cannot be converted to a cookbook procedure. This is because every system has a different architecture (composition and function) making the end product different. It takes "systems thinking" skill to make the derived information relevant to the information goal." If we want to identify premises for successful application of the SAF in various ICM systems, then we must properly address the gap between the broad-scale scientific knowledge and methods applied in the SAF, and how important, credible, and useful these methods are considered at the regional level, referring to differing cultural and historical backgrounds [3].

This is where Finland could give a good example of proper addressing local and regional stakeholder needs and balancing them in ICM and maritime spatial planning processes. In Finland, interest in ICM had grown by the end of the 20th century following a widespread acknowledgement that the coastal zone, due to its exceptional dynamism and concentration of conflicting interests, requires different planning approaches than those traditionally applied to spatial planning. In Finland, the development of ICM plans was left to the responsibility of the regions. One level below, the implementation of the regional ICM plans was largely a responsibility of local self-governments, coordinated by regional authorities.

In the SAF process, the assessment of the central ecological, social, and economic issues mainly focuses on an impact in an ecological system [1]. The benefits of applying proper assessment tools are in better understanding of the functional relationship between the impact and its cause. This provides the basis for necessary links of the economic and social responses to the impact required for simulating policy options, although the SAF deliberately does not include the dynamics of policymaking [2]. What concerns models, scenarios, and cost-benefit analysis, in the SAF process they are important 
because the SAF must have the capacity to quantify the past, current, and future changes in the system and to assess whether those changes are oriented towards greater or lesser sustainability [2].

The development, approval, and implementation of the ICM plans extensively included regional stakeholders and the general public throughout the entire design and approbation process. The most important lessons learned, in terms of the SAF, from the two Finnish case studies are the following: (1) continuous funding and integration of ICM planning into existing national and/or regional spatial planning system is critically important for the success of ICM; (2) active and continuous inclusion of stakeholders and the general public to ensure a shared understanding of ICM; and (3) making the best use of up-to-date GIS information for more detailed identification of conflict points in the area.

Concerning the role of communication, one of the key preconditions for a successful SAF process is the unrestricted exchange of both matter and meaning by establishing the 'pathways of communication' between the entities that make up the coastal system [3]. As articulated by Hopkins et al. [1]: "In a democratic decision process when the facts are unfamiliar, a judgment on their verity will often reflect subjective arguments more than factual. Recognizing this, the SAF places great emphasis on providing relevant information in an accessible form to the public." However, Støttrup et al. [4] pointed out regarding BaltCoast, that in many re-analyzed case studies, the oversight of stakeholder and institutional mapping had led to inadequate representation of stakeholders, or in some cases, lack of involvement of stakeholders at the start of the process, which proved to be a substantial impediment in the advance of ICM.

\section{Conclusions}

In spite of international and national long-term efforts, ICM implementation in the Baltic States and Kaliningrad Oblast of Russia still has not been fully adopted and implemented, especially when taking into account local-level specifics. In many respects, the re-analyzed ICM Policy Issues are missing the SES content to be addressed by multidisciplinary studies, cross-sectorial and cross-level integration, as well as real stakeholders' participation in the decision-making process [30]. Besides the simulation model-based grounding of coastal zone development scenarios, a truly dedicated involvement of a wide range of stakeholders throughout all process stages is critical for further successful advance of the SAF-based ICM processes and principles in all the Baltic States and, particularly, in the Russian Federation.

For avoiding these and many other ICM deficiencies, the aforementioned coastal collaborative 'communication pathways' [3] must be developed. Additionally, integration of ICM and maritime spatial planning into the statutory national spatial planning systems is critically important for a long-term, SAF-based ICM, as the case studies from Finland show. In this way, the SAF-based ICM in the Baltic States would be made more compatible with the EU MSP Directive.

Author Contributions: Conceptualization, E.B. and R.P.; methodology, R.P.; validation, E.B. and K.D.; formal analysis, E.B., R.P. and K.D.; investigation, R.E. and H.T.; data curation, R.P., R.E. and H.T.; writing-original draft preparation, E.B. and R.P.; writing - review and editing, E.B. and R.P.; visualization, K.D. All authors have read and agreed to the published version of the manuscript.

Funding: This research received no external funding.

Conflicts of Interest: The authors declare no conflict of interest.

\section{References}

1. Hopkins, T.S.; Bailly, D.; Elmgren, R.; Glegg, G.; Sandberg, A.; Støttrup, J.G. A systems approach framework for the transition to sustainable development: Potential value based on coastal experiments. Ecol. Soc. 2012, 17. [CrossRef]

2. Hopkins, T.S.; Bailly, D.; Støttrup, J.G. A systems approach framework for coastal zones. Ecol. Soc. 2011, 16. [CrossRef]

3. McFadden, L.; Schernewski, G. Critical reflections on a systems approach application in practice: A Baltic lagoon case study. Reg. Environ. Chang. 2014, 14, 2115-2126. [CrossRef] 
4. Støttrup, J.G.; Dinesen, G.E.; Janßen, H.; Gillgren, C.; Schernewski, G. Re-visiting ICM theory and practice: Lessons learned from the Baltic Sea Region. Ocean Coast. Manag. 2017, 139, 64-76. [CrossRef]

5. Reis, J. Introduction to systems approaches in coastal management-The legacy of the SPICOSA project. Mar. Policy 2014, 43, 1-2. [CrossRef]

6. Newton, A. Guest Editorial, part of a Special Feature on A Systems Approach for Sustainable Development in Coastal Zones. Ecol. Sci. 2012, 17, 3-4. [CrossRef]

7. Reis, J.; Lowe, C. Capacity development of European coastal and marine management-gaps and bridges. Ocean Coast. Manag. 2012, 55, 13-19. [CrossRef]

8. Lowe, C.D.; Gilbert, A.J.; Mee, L.D. Human-environment interaction in the Baltic Sea. Mar. Policy 2014, 43, 46-54. [CrossRef]

9. Pickaver, A.; Steijn, R.; Ferreira, M.; Czerniak, P.; Devilee, E.; Gault, J.; Heinichen, B.; Hill, O.; Körfer, A.; Krivokhizhin, S.; et al. Integrated Coastal Zone Management: Participation and Practices in Europe; Publications Office of the European Union: Luxembourg, 2010; ISBN 978-9279-16201-5. [CrossRef]

10. HELCOM. Eutrophication Status of the Baltic Sea 2007-2011-A Concise Thematic Assessment; Balt. Sea Environ. Proc. No. 143; HELCOM: Helsinki, Finland, 2014; Volume 41.

11. Roepstorff, A.; Povilanskas, R. On the concepts of nature protection and sustainable use of natural resources: A case study from the Curonian lagoon. In Coastal Conservation and Management in the Baltic Region, Proceedings of the EUCC-WWF Conference, Klaipeda, Lithuania, 2-8 May 1994; Gudelis, V., Povilanskas, R., Roepstorff, A., Eds.; University Publishers: Klaipėda, Lithuania, 1995; pp. 223-232.

12. Povilanskas, R.; Razinkovas-Baziukas, A.; Jurkus, E. Integrated environmental management of transboundary transitional waters: Curonian Lagoon case study. Ocean Coast. Manag. 2014, 101, 14-23. [CrossRef]

13. Ojaveer, E. National ICZM strategies in Estonia ICZM in Estonia General strategy. Coastline Rep. 2004, 2, 17-21.

14. Kont, A.; Jaagus, J.; Orviku, K.; Palginõmm, V.; Ratas, U.; Rivis, R.; Suursaar, Ü.; Tõnisson, H. Natural Development and Human Activities on Saaremaa Island (Estonia) in the Context of Climate Change and Integrated Coastal Zone Management. Coast. Res. Libr. 2011, 1, 117-134. [CrossRef]

15. Kask, A.; Soomere, T.; Suuroja, S.; Kask, J. Sand accumulation under varying lithohydrodynamic conditions in the coastal area of the north-eastern Baltic Sea. Baltica 2010, 23, 157-164.

16. Palginõmm, V.; Ratas, U.; Kont, A. Increasing human impact on coastal areas of Estonia in recent decades. J. Coast. Res. 2007, 50, 114-119.

17. Tamme, T.; Rivis, R. Rivis Monitoring and management of visitor flows in recreational and protected areas-a case study from Aegna Island Estonia. J. Coast. Res. 2011, 64, 1302-1305.

18. Tõnisson, H.; Orviku, K.; Jaagus, J.; Suursaar, Ü.; Kont, A.; Rivis, R. Coastal damages on Saaremaa Island, Estonia, caused by the extreme storm and flooding on January 9, 2005. J. Coast. Res. 2008, 24, 602-614. [CrossRef]

19. Tõnisson, H.; Suursaar, Ü.; Orviku, K.; Jaagus, J.; Kont, A.; Willis, D.A.; Rivis, R. Changes in coastal processes in relation to changes in large-scale atmospheric circulation, wave parameters and sea levels in Estonia. J. Coast. Res. 2011, SI 64, 701-705.

20. Brunina, L.; Rivza, P.; Konstantinova, E. Coastal spatial planning problems in Latvia. J. Coast. Res. 2011, 64, 1224-1227.

21. Eberhards, G.; Lapinskis, J. Processes on the Latvian coast of the Baltic Sea; Latvijas Universitāte: Rīga, Latvia, 2008; p. 64.

22. Lagzdina, E.; Kudrenickis, I.; Ernsteins, R.; Kaulins, J. COASTAL sustainable DEVELOPMENT STUDIES in Latvia: INTEGRATED local social-ecological systems governance. Reg. Form. Dev. Stud. 2017, 21, 83-96. [CrossRef]

23. Brunina, L. Measurement Methodology of Losses Due To Erosion of Coastal Area in Latvia. Econ. Rural Dev. 2011, 7, 7-13.

24. Eberhards, G.; Lapinskis, J.; Saltupe, B. Hurricane Erwin 2005 coastal erosion in Latvia. Baltica 2006, 19, 10-19.

25. Eberhards, G.; Grine, I.; Lapinskis, J.; Purgalis, I.; Saltupe, B.; Torklere, A. Changes in Latvia's seacoast (1935-2007). Baltica 2009, 22, 11-22.

26. Ernsteins, R.; Kaulins, J.; Lice, E.; Štals, A. Integrated coastal management for local municipalities in Latvia: Sustainability governance and indicator system. WIT Trans. Ecol. Environ. 2011, 149, 29-40. [CrossRef] 
27. Ernsteins, R. Development of municipal and social resilience understanding: Stakeholder complementary training on coastal governance and communication. Int. Multidiscip. Sci. GeoConference SGEM 2012, 5, 1007.

28. Ernšteins, R.; Lontone, A.; Kaulinš, J.; Zvirbule, L.; Strazdinš, J.; Šteinberga, Z.; Ivars, K.; Zīlniece, I.; Kepals, A. Municipal Climate Change Adaptation governance in Latvia: Approaching Cross-sectoral and Multi-instrumental understanding. Reg. Form. Dev. Stud. 2014, 3, 40-52. [CrossRef]

29. Ernsteins, R.; Kudrenickis, I.; Lontone-Ievina, A.; Kaulins, J.; Urtans, A.V. Municipal sustainable coastal governance: Participatory approaches for system analysis and for local monitoring development. WSEAS Trans. Environ. Dev. 2017, 13, 276-290.

30. Ernsteins, R.; Lontone-Ievina, A.; Lagzdina, E.; Osniece, K.; Kaulins, J. Integrated Coastal Management Practice Case Studies: Deficiency of Collaboration Communication and Socio-Ecological System Approaches. Econ. Sci. Rural Dev. Conf. Proc. 2017, 45, 63-70.

31. Kudrenickis, I.; Ernsteins, R.; Kaulins, J. Sustainable Coastal Science-Policy-Practice Interface Development: Municipal Coastal Governance Indicator System. Int. J. Educ. Learn. Syst. 2016, 1, 255-264.

32. Povilanskas, R.; Urbis, A. National ICZM strategy and initiatives in Lithuania. Coastline Rep. 2004, 2, 9-15.

33. Bitinas, A.; Žaromskis, R.; Gulbinskas, S.; Damušyte, A.; Žilinskas, G.; Jarmalavičius, D. The results of integrated investigations of the Lithuanian coast of the Baltic Sea: Geology, geomorphology, dynamics and human impact. Geol. Q. 2005, 49, 355-362.

34. Jarmalavičius, D.; Satkūnas, J.; Žilinskas, G.; Pupienis, D. Dynamics of beaches of the Lithuanian coast (the Baltic Sea) for the period 1993-2008 based on morphometric indicators. Environ. Earth Sci. 2012, 65, 1727-1736. [CrossRef]

35. Pupienis, D.; Jonuškaite, S.; Jarmalavičius, D.; Žilinskas, G. Klaipejda port jetties impact on the Baltic Sea shoreline dynamics, Lithuania. J. Coast. Res. 2013, 165, 2167-2172. [CrossRef]

36. Žilinskas, G. Distinguishing priority sectors for the Lithuanian Baltic Sea coastal management. Baltica 2008, 21, 85-94.

37. Kriaučiuniene, J.; Žilinskas, G.; Pupienis, D.; Jarmalavičius, D.; Gailiušis, B. Impact of Šventoji port jetties on coastal dynamics of the Baltic sea. J. Environ. Eng. Landsc. Manag. 2013, 21, 114-122. [CrossRef]

38. Povilanskas, R.; Armaitienè, A.; Dyack, B.; Jurkus, E. Islands of prescription and islands of negotiation. J. Destin. Mark. Manag. 2016, 5, 260-274. [CrossRef]

39. Pupienis, D.; Jarmalavičius, D.; Žilinskas, G.; Fedorovič, J. Beach nourishment experiment in Palanga, Lithuania. J. Coast. Res. 2014, 70, 490-495. [CrossRef]

40. Žilinskas, G.; Pupienis, D.; Jarmalavičius, D. Possibilities of regeneration of palanga coastal zone. J. Environ. Eng. Landsc. Manag. 2010, 18, 92-101. [CrossRef]

41. Morkūnaitè, R.; Bautrènas, A.; Česnulevičius, A.; Dobrotin, N.; Baubinienè, A.; Jankauskaitè, M.; Kalesnikas, A.; Mačiulevičiūtè-Turlienè, N. Changes in quantitative parameters of active wind dunes on the south-east Baltic Sea coast during the last decade (Curonian Spit, Lithuania). Geol. Q. 2017, 62, 38-47. [CrossRef]

42. Povilanskas, R.; Riepšas, E.; Armaitienè, A.; Dučinskas, K.; Taminskas, J. Shifting dune types of the Curonian spit and factors of their development. Balt. For. 2011, 17, 215-226.

43. Povilanskas, R.; Armaitienè, A.; Breber, P.; Razinkovas-Baziukas, A.; Taminskas, J. Integrity of linear littoral habitats of Lesina and Curonian Lagoons. Hydrobiologia 2012, 699, 99-110. [CrossRef]

44. Porotov, A. Kaliningrad. Encyclopedia of the World's Coastal Landforms; Bird, E.C.F., Ed.; Springer: Dordrecht, The Netherlands, 2010; pp. 623-626. [CrossRef]

45. Burnashov, E.; Chubarenko, B.; Stont, Z. Natural evolution of western shore of the sambian peninsula on completion of dumping from an amber mining plant. Arch. Hydroengineering Environ. Mech. 2010, 57, 105-117.

46. Chechko, V.A.; Chubarenko, B.V.; Boldyrev, V.L.; Bobykina, V.P.; Kurchenko, V.Y.; Domnin, D.A. Dynamics of the marine coastal zone of the sea near the entrance moles of the Kaliningrad Seaway Channel. Water Resour. 2008, 35, 652-661. [CrossRef]

47. Kosyan, R. The Diversity of Russian Estuaries and Lagoons Exposed to Human Influence; Springer: Cham, Switzerland, 2017. [CrossRef] 
48. Kropinova, E.G. The Reduction in the Beach Area as the Main Limiting Factor for Sustainable Tourism Development (Case for the Kaliningrad Oblast). Terrestrial and Inland Water Environment of the Kaliningrad Region. The Handbook of Environmental Chemistry; Gritsenko, V.A., Sivkov, V.V., Yurov, A.V., Kostianoy, A.G., Eds.; Springer: Cham, Switzerland, 2017; Volume 65.

49. Gari, S.R.; Newton, A.; Icely, J.; Lowe, C.D. Testing the application of the systems approach framework (SAF) for the management of eutrophication in the Ria Formosa. Mar. Policy 2014, 43, 40-45. [CrossRef]

50. Schernewski, G.; Schumacher, J.; Weisner, E.; Donges, L. A combined coastal protection, realignment and wetland restoration scheme in the southern Baltic: Planning process, public information and participation. J. Coast. Conserv. 2018, 22, 533-547. [CrossRef]

51. Tett, P.; Sandberg, A.; Mette, A. Sustaining Coastal Zone Systems; Dunedin Academic Press Ltd: Edinburg, UK, 2011. [CrossRef]

52. Schernewski, G.; Bartel, C.; Kobarg, N.; Karnauskaite, D. Retrospective assessment of a managed coastal realignment and lagoon restoration measure: The Geltinger Birk, Germany. J. Coast. Conserv. 2018, 22, 157-167. [CrossRef]

53. Semeoshenkova, V.; Newton, A.; Rojas, M.; Piccolo, M.C.; Bustos, M.L.; Huamantinco Cisneros, M.A.; Berninsone, L.G. A combined DPSIR and SAF approach for the adaptive management of beach erosion in Monte Hermoso and Pehuen Co (Argentina). Ocean Coast. Manag. 2017, 143, 63-73. [CrossRef]

Publisher's Note: MDPI stays neutral with regard to jurisdictional claims in published maps and institutional affiliations. 